\title{
Genetic Diversity of Tunisian and Chinese Alfalfa (Medicago sativa L.) Revealed by RAPD and ISSR Markers
}

\author{
Leila Touil ${ }^{1,2}$, Aike Bao ${ }^{2}$, Suomin Wang ${ }^{2}$, Ali Ferchichi ${ }^{1}$ \\ ${ }^{1}$ Arid Land and Oasis Cropping Laboratory, Institute of Arid Land, Medenine, Tunisia \\ ${ }^{2}$ State Key Laboratory of Grassland Agro-Ecosystems, College of Pastoral Agriculture Science and Technology, \\ Lanzhou University, Lanzhou, China \\ Email: "leila.touil@yahoo.fr
}

Received 3 March 2016; accepted 26 April 2016; published 29 April 2016

Copyright (C) 2016 by authors and Scientific Research Publishing Inc.

This work is licensed under the Creative Commons Attribution International License (CC BY). http://creativecommons.org/licenses/by/4.0/

\section{(c) (i) Open Access}

\begin{abstract}

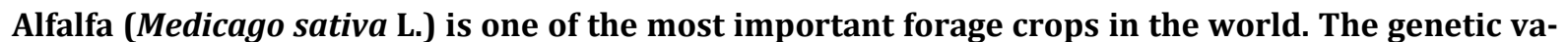
riability analysis of 19 alfalfa populations collected from three sites in South Tunisia (Gabes, Kebili, Tozeur) and 1 from North West China were carried out using Random Amplified Polymorphic DNA (RAPD) and Inter Simple Sequence Repeat (ISSR) markers. Five RAPD primers amplified 44 bands of which 22 were polymorphic; and five ISSR primers amplified 51 bands of which 33 were polymorphic. The percentage of polymorphic bands detected by RAPD and ISSR was 50\% and $64.7 \%$, respectively. The resolving power (Rp) varied between 0.6 and 4.1 with an average of 2.02 for RAPD marker and between 0.7 and 6.5 with an average of 2.28 for ISSR marker. However the Average Informativeness band (AvIb) was ranged from 0.2 to 0.9 with an average of 0.5 in RAPD marker and from 0.29 to 0.7 with an average of 0.624 in ISSR marker. The RAPD marker revealed less within population genetic diversity than ISSR marker. Although Cluster (UPGMA) and Correspondence Factorial Analyses (CFA) indicate that populations' clustering made independently both from the geographical origin.
\end{abstract}

Keywords

Medicago sativa L., Genetic Variability, RAPD, ISSR, UPGMA Clustering

\section{Introduction}

Alfalfa (Medicago sativa L.) is important legume forage that contains a variety of vitamins and high protein

"Corresponding author.

How to cite this paper: Touil, L., Bao, A.K., Wang, S.M. and Ferchichi, A. (2016) Genetic Diversity of Tunisian and Chinese Alfalfa (Medicago sativa L.) Revealed by RAPD and ISSR Markers. American Journal of Plant Sciences, 7, 967-979.

http://dx.doi.org/10.4236/ajps.2016.76092 
content and thus is a key component of the animal husbandry all over the world. Lucerne is a good plant model for studies of genetics. Many reports have been documented regarding genetic diversity of Medicago sativa using different traits: morphological and yield [1]-[3], histological [4] and allozyme markers [5].

Neutral, DNA-based molecular markers allow a more precise and environment-independent way to evaluate the genetic diversity of a particular species. Several studies have been done on alfalfa using DNA-based markers like AFLP [6] [7], RAPD [8]-[13], RFLP [14]-[17] and SSR [18]-[20]. These studies have shown that alfalfa was characterized by a high inter-population variability.

Among different markers (morphological, cytological biochemical and DNA), markers based on DNA are independent from environmental effects, unlimited in number and show high level of polymorphism.

Random Amplified Polymorphic DNA (RAPD) is generally favored because of its sensitivity, coupled with the fact that DNA sequence information is not required for primer design, no radioisotope labeling is needed for sample detection, and only a small amount of template DNA is required [21] [22]. RAPD is a molecular marker widely used in genetic variability analyses due to its simplicity and speed, dispensing previous genetic information of the sample under study [23]; although no locus specific information is presented [24]. Basically, it's a variation of the PCR amplification technique, using a simple primer of arbitrary sequence that will amplify a random region of the analyzed genome. Even though the reproducibility of this marker has been previously questioned [25], adjustment in the technique has made the obtainment of reproducible results possible [26] permitting the use of this markers in many types of genetic analysis.

ISSR markers are generated via PCR reactions with a single primer designed from repetitions of two or three nucleotides anchored in a sequence of one to three nucleotides that aim to eliminate slippage related artifacts [27]. The amplified regions represent the sequence between two microsatellite sites and the absence of bands is interpreted as a divergence of the primer or loss of a locus by the deletion of the SSR sites or chromosomal rearrangement. Some advantages related to this marker are the small quantity of DNA required for the reactions, the small number of PCR reactions, the hyper variability of the bands patterns and their easy detection, besides the high PCR reactions annealing temperatures that reduce the quantity of artifacts and errors [28].

The objective of this study was to investigate the differentiation level among a set of alfalfa populations with RAPD and ISSR markers, and to examine the relationship between these populations collected from tow semi arid regions (the South of Tunisia and the North West of China) and their genomic diversity in order to complete genetic resources conservation and the evaluation of native germplasm of lucerne and constitute a base for breeding program.

\section{Materials and Methods}

\subsection{Plant Material}

Twenty alfalfa (Medicago sativa L.) populations were involved in this study, including nineteen from South Tunisia and one from North Ouest of China. The description of the 20 alfalfa genotypes used in this study was resumed in Table 1.

\subsection{Genetic Diversity Analysis}

\subsubsection{DNA Extraction}

Young leaflets were harvested on each plant and total genomic DNA was purified from frozen young leaves according to the procedure described by [29] with minor modifications. The genomic DNA concentration was estimated spectrophotometrically and its integrity was checked by analytical (2\%) agarose minigel electrophoresis [30].

\subsubsection{RAPD Assay}

Five random decamer primers were used for DNA amplifications (Table 2). Polymerase chain reaction for each sample was performed in a total volume of $20 \mu \mathrm{l}$. The PCR (Polymerisation Chain Reaction) reaction mixture contained $50 \mathrm{ng}$ genomic DNA, $1.5 \mathrm{mM} \mathrm{MgCl} 2,0.2 \mathrm{mM}$ dNTPs, $0.5 \mu \mathrm{M}$ primer and $1 \mathrm{U}$ Taq polymerase (Promega), 10× Taq polymerase buffer. PCR amplifications were performed in a Thermocycleur TC32/80 Cleaver scientific LTD system. The PCR conditions included initial denaturation at $94^{\circ} \mathrm{C}$ for $5 \mathrm{~min}$, followed by 45 cycles: denaturation at $94^{\circ} \mathrm{C}$ for $1 \mathrm{~min}$, annealing at $\mathrm{Tm}^{\circ} \mathrm{C}$ of each primer $(1 \mathrm{~min})$, extension at $72^{\circ} \mathrm{C}$ for $1 \mathrm{~min}$ 
Table 1. Tunisian and Chinese alfalfa populations studied and their geographical origin.

\begin{tabular}{|c|c|c|c|}
\hline Accession Name & Label & Geographical origin & Oases type \\
\hline Kattana & $\mathrm{P} 1$ & Gabès & Coastal \\
\hline Chenchou & P2 & Gabès & Coastal \\
\hline Cheninni 1 & P3 & Gabès & Coastal \\
\hline Cheninni 2 & P4 & Gabès & Coastal \\
\hline Cheninni 3 & P5 & Gabès & Coastal \\
\hline Teboulbou & P6 & Gabès & Coastal \\
\hline Metwia & P7 & Gabès & Coastal \\
\hline Ghannouch & P8 & Gabès & Coastal \\
\hline Zerkine & P9 & Gabès & Coastal \\
\hline Essdada & P10 & Tozeur & Continental \\
\hline Bouhlel & P11 & Tozeur & Continental \\
\hline Degach & $\mathrm{P} 12$ & Tozeur & Continental \\
\hline Hamma jerid & P13 & Tozeur & Continental \\
\hline Zaafarane & P14 & Kébili & Continental \\
\hline Nouael & P15 & Kébili & Continental \\
\hline Jerzinze & P16 & Kébili & Continental \\
\hline El golaa & $\mathrm{P} 17$ & Kébili & Continental \\
\hline Limaguess & P18 & Kébili & Continental \\
\hline Staftimia & P20 & Kébili & Continental \\
\hline Xinjiang Daye & P21 & North Ouest China & Continental \\
\hline
\end{tabular}

Table 2. List of the selected RAPD primers and the polymorphisms obtained on 20 alfalfa populations.

\begin{tabular}{cccccccc}
\hline Primers & $\begin{array}{c}\text { Sequence } \\
\left(5^{\prime}-3^{\prime}\right)\end{array}$ & $\operatorname{Tm}\left({ }^{\circ} \mathrm{C}\right)$ & $\begin{array}{c}\text { Total number } \\
\text { of bands (a) }\end{array}$ & $\begin{array}{c}\text { Number of } \\
\text { polymorphic } \\
\text { bands (b) }\end{array}$ & $\begin{array}{c}\text { Percentage of } \\
\text { polymorphism } \\
(\mathrm{a} / \mathrm{b})\end{array}$ & $\begin{array}{c}\text { Resolving } \\
\text { power (Rp) }\end{array}$ & $\begin{array}{c}\text { Average } \\
\text { Informativeness } \\
\text { band (AvIb) }\end{array}$ \\
\hline AF14 & GGTGCGCACT & 34 & 13 & 8 & 61.53 & 4.1 & 0.51 \\
C1 & TTCGAGCCAG & 32 & 7 & 3 & 42.85 & 0.6 & 0.2 \\
AX16 & GTCTGTGGGG & 34 & 8 & 3 & 37.5 & 1.9 & 0.63 \\
AT & CAGTGGTTCC & 32 & 9 & 7 & 77.77 & 2.6 & 0.37 \\
W-07 & CTGGACGTCA & 32 & 7 & 1 & 14.28 & 0.9 & 0.9 \\
\hline
\end{tabular}

with final extension at $72^{\circ} \mathrm{C}$ for $7 \mathrm{~min}$. Amplification products were loaded on $1.8 \%$ agarose gel, by electrophoresis in TBE buffer, stained with ethidium bromide, visualized by illumination with ultraviolet light and photographed under UV light, by a Bioprint (Kaiser RS1, Germany).

\subsubsection{ISSR Assay}

Five primers were used for PCR amplification (Table 3). PCR was carried out at $20 \mu \mathrm{L}$ final volume using 25 ng of genomic DNA containing $4 \mu \mathrm{L}$ of $5 \times$ Green GoTaqR (pH 8.5, $7.5 \mathrm{mM} \mathrm{MgCl2}$ ), $100 \mu \mathrm{M}$ dNTPs, 150 pmol random primer, and 1.2 units of Taq DNA polymerase. The mixture was brought up to $20 \mu \mathrm{L}$ by adding 
Table 3. List of the selected ISSR primers and the polymorphisms obtained on 20 alfalfa populations.

\begin{tabular}{cccccccc}
\hline Primers & $\begin{array}{c}\text { Sequence } \\
\left(5^{\prime}-3^{\prime}\right)\end{array}$ & Tm $\left({ }^{\circ} \mathrm{C}\right)$ & $\begin{array}{c}\text { Total number } \\
\text { of bands (a) }\end{array}$ & $\begin{array}{c}\text { Number of } \\
\text { polymorphic } \\
\text { bands (b) }\end{array}$ & $\begin{array}{c}\text { Percentage of } \\
\text { polymorphism } \\
(\mathrm{a} / \mathrm{b})\end{array}$ & $\begin{array}{c}\text { Resolving } \\
\text { power (Rp) }\end{array}$ & $\begin{array}{c}\text { Average } \\
\text { Informativeness } \\
\text { band (AvIb) }\end{array}$ \\
\hline A1 & AGAGAGAGAGAGAGAGC & 53 & 13 & 8 & 61.53 & 4.1 & 0.51 \\
Am2 & TCTCTCTCTCTCTCTCC & 53 & 7 & 3 & 42.85 & 0.6 & 0.2 \\
UBC 890 & (AGC)(ACT)(AGC)(GT)7 & 51.9 & 8 & 3 & 37.5 & 1.9 & 0.63 \\
A12 & (GA) 6 CC & 55 & 9 & 7 & 77.77 & 2.6 & 0.37 \\
UBC-818 & (CA)7G & 52 & 7 & 1 & 14.28 & 0.9 & 0.9 \\
\hline
\end{tabular}

sterilized distilled water. The mixture was amplified in a thermal cycler (GeneAmpR PCR System 9700) that was programmed for 1 cycle of initial denaturation at $94^{\circ} \mathrm{C}$ for $5 \mathrm{~min}$; 35 cycles of $94^{\circ} \mathrm{C}$ for $1 \mathrm{~min}$, followed by specific annealing temperature for $55 \mathrm{~s}$, and ending with an extension at $72^{\circ} \mathrm{C}$ for $1 \mathrm{~min}$; and a final extension cycle at $72^{\circ} \mathrm{C}$ for $7 \mathrm{~min}$. The PCR machine was adjusted to hold the product at $4^{\circ} \mathrm{C}$. The PCR products and $1 \mathrm{~kb}$ DNA ladder were electrophoresed on $2 \%$ agarose gel (stained with EtBr). The separated fragments were visualized with an ultraviolet (UV) transilluminator.

\subsection{Data Analysis}

Each gel after electrophoresis and staining was analysed by scoring manually the present (1) and absent (0) polymorphic RAPD and ISSR bands in individual lines for each primer and the values were used to compile binary data matrix.

For all primers combination, the total number of bands was determined and only the polymorphic ones were taken into account in this study to estimate the percentage of polymorphic bands (\%PB).

The similarity matrix was calculated with Jaccard's coefficient [31]. The matrix was then analyzed with the Neighbor-joining program using PHYLIP software (Phylogeny Inference Package, version 3.5c) [32] to construct a dendrogram between 19 Tunisian and 1 Chinese alfalfa populations using the unweighted pair group method with arithmetic averaging (UPGMA) algorithm.

The ability of the most informative primers to discriminate among populations was assessed by calculating the resolving power (Rp) [33] which has been reported to correlate between accessions. Evaluation of the Rp was performed according to the formula of $[34]$ : $\mathrm{Rp}=\Sigma \mathrm{Ib}$, where: $\mathrm{Ib}=1-[2 *|0.5-P|]$, Ib is the informativness band and $P$ is the proportion of the accessions containing the I band. Average Informativeness band (AvIb) as a measure of closeness of a band to be present in $50 \%$ of the genotypes in this study, was also calculated.

On the other hand, a correspondence factorial analysis (CFA) was performed by computing the binary matrix with XLSTAT version 14.

\section{Results}

\subsection{RAPD Markers in Determining Genetic Variation of Alfalfa Populations}

In order to detect genetic variation between 20 alfalfa populations, PCR amplifications were performed with RAPD primers. A total of five primers were screened in this study and produced discrete and reproducible amplified DNA fragments (Figure 1). The five RAPD primers resulted in 44 different amplification products with 22 polymorphic RAPD bands for the 20 populations (Table 2).

Different levels of polymorphisms were detected since as the percentage of polymorphic bands (\%PB) ranged from 14.28 for W07 to 77.77 for AT primers, with an average of $46.02 \%$.

The percentage of polymorphic bands detected by RAPD marker was $50 \%$ and the average of polymorphic bands per RAPD primers was 10\%. The largest number of polymorphic bands (8) was produced with AF14 primer, and the least number of polymorphic bands (1) was obtained by W07. The 5 polymorphic primers exhibited variation with regard to Average Informativeness band (AvIb) and resolving power (Rp). However, estimates of the resolving power (Rp) showed a high rate of collective Rp (10.1), with an average of 2.02. 


\section{P1 P2 P3 P4 P5 P6 P7 P8 P9 P10 P11 P12 P13 P14 P15 P16 P17 P18 P20 P21}

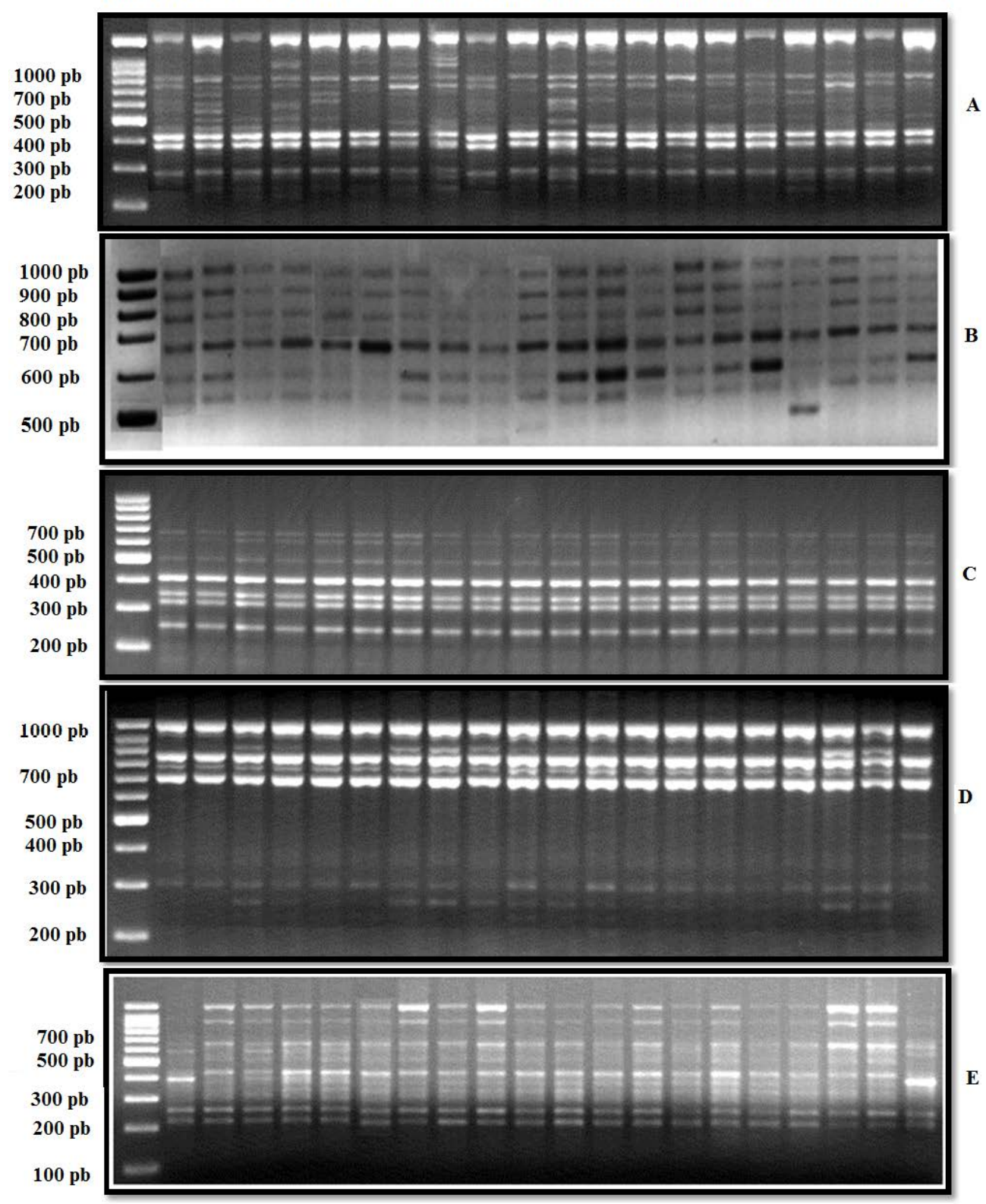

Figure 1. RAPD bands amplified with five arbitrary primers: (A) AF 14, (B) C1, (C) AX16, (D) AT and (E) W07, using DNA of 20 Tunisian and Chinese alfalfa samples. Numbers represent the populations according to Table 1. MM: Molecular Marker.

Moreover, as reported in Table 2, the Average Informativeness band (AvIb) values varied from 0.2 showed by the primer $\mathrm{C} 1$ to 0.9 showed by the primer W07, with an average of 0.522 .

The similarity matrix (Table 4) showed that the highest similarity (0.87) was for the populations P4, P5, P10, P13 and P18, P1, P14, P15 and P16, P2 and P11. The lowest similarity (0.55) was between the populations P21, p20, P4, P1, P11, P18, P10 and P13.

The derived UPGMA dendrogram illustrated in Figure 2 has clustered the 20 populations into seven main groups. The three first groups, labeled (I, II, III), successively, consisted of "Xinjiang Daye" (Provenance Chine), P20: Stiftimia (Provenance Kébili) and P2: Chenchou (Provenance Gabès) et P11: Bouhlel (Provenance Tozeur). The fourth group labeled (IV) consisted of P1: Kattana (Provenance Gabès), P14: Zaafarane, P15: Nouael et P16: Jersine (Provenance Kébili) populations. The fifth group (V) consisted of P4: Chenenni1, P5: 
Table 4. Similarity matrix among 20 alfalfa populations based on data from 5 RAPD primers (44RAPD markers).

\begin{tabular}{|c|c|c|c|c|c|c|c|c|c|c|c|c|c|c|c|c|c|c|c|c|}
\hline & P1 & P2 & P3 & P4 & P5 & P6 & P7 & P8 & P9 & P10 & P11 & P12 & P13 & P14 & P15 & P16 & P17 & P18 & P20 & P21 \\
\hline P1 & 1 & & & & & & & & & & & & & & & & & & & \\
\hline P2 & 0.7 & 1 & & & & & & & & & & & & & & & & & & \\
\hline P3 & 0.74 & 0.83 & 1 & & & & & & & & & & & & & & & & & \\
\hline P4 & 0.67 & 0.8 & 0.88 & 1 & & & & & & & & & & & & & & & & \\
\hline P5 & 0.68 & 0.87 & 0.85 & 0.82 & 1 & & & & & & & & & & & & & & & \\
\hline P6 & 0.66 & 0.76 & 0.74 & 0.81 & 0.78 & 1 & & & & & & & & & & & & & & \\
\hline P7 & 0.68 & 0.82 & 0.9 & 0.92 & 0.8 & 0.83 & 1 & & & & & & & & & & & & & \\
\hline P8 & 0.68 & 0.77 & 0.8 & 0.87 & 0.74 & 0.83 & 0.89 & 1 & & & & & & & & & & & & \\
\hline P9 & 0.71 & 0.81 & 0.84 & 0.82 & 0.78 & 0.77 & 0.84 & 0.89 & 1 & & & & & & & & & & & \\
\hline P10 & 0.69 & 0.79 & 0.82 & 0.84 & 0.76 & 0.75 & 0.87 & 0.86 & 0.91 & 1 & & & & & & & & & & \\
\hline P11 & 0.77 & 0.87 & 0.85 & 0.82 & 0.84 & 0.78 & 0.84 & 0.84 & 0.83 & 0.81 & 1 & & & & & & & & & \\
\hline P12 & 0.75 & 0.8 & 0.83 & 0.85 & 0.82 & 0.81 & 0.87 & 0.82 & 0.81 & 0.79 & 0.92 & 1 & & & & & & & & \\
\hline P13 & 0.79 & 0.78 & 0.82 & 0.84 & 0.86 & 0.85 & 0.81 & 0.81 & 0.85 & 0.83 & 0.86 & 0.89 & 1 & & & & & & & \\
\hline P14 & 0.81 & 0.75 & 0.74 & 0.76 & 0.82 & 0.76 & 0.73 & 0.77 & 0.82 & 0.79 & 0.82 & 0.8 & 0.9 & 1 & & & & & & \\
\hline P15 & 0.79 & 0.84 & 0.82 & 0.8 & 0.81 & 0.8 & 0.82 & 0.81 & 0.86 & 0.78 & 0.86 & 0.89 & 0.88 & 0.85 & 1 & & & & & \\
\hline P16 & 0.87 & 0.81 & 0.79 & 0.76 & 0.78 & 0.77 & 0.78 & 0.78 & 0.82 & 0.8 & 0.88 & 0.86 & 0.91 & 0.93 & 0.91 & 1 & & & & \\
\hline P17 & 0.65 & 0.75 & 0.69 & 0.71 & 0.77 & 0.87 & 0.73 & 0.77 & 0.77 & 0.79 & 0.77 & 0.7 & 0.79 & 0.81 & 0.74 & 0.76 & 1 & & & \\
\hline P18 & 0.69 & 0.79 & 0.82 & 0.84 & 0.76 & 0.8 & 0.87 & 0.91 & 0.97 & 0.89 & 0.81 & 0.84 & 0.83 & 0.79 & 0.89 & 0.8 & 0.74 & 1 & & \\
\hline P20 & 0.69 & 0.79 & 0.87 & 0.84 & 0.81 & 0.8 & 0.87 & 0.86 & 0.97 & 0.89 & 0.81 & 0.84 & 0.88 & 0.79 & 0.83 & 0.8 & 0.74 & 0.94 & 1 & \\
\hline P21 & 0.84 & 0.69 & 0.77 & 0.74 & 0.76 & 0.69 & 0.72 & 0.67 & 0.7 & 0.73 & 0.71 & 0.74 & 0.82 & 0.74 & 0.73 & 0.74 & 0.64 & 0.68 & 0.73 & 1 \\
\hline
\end{tabular}

Chenenni2, P6: Chenenni3 (Provenance Gabès), P10: Essdada, P13: Hamma jerid (Provenance Tozeur) et P18: Limaguess (Provenance Kébili) populations. The sixth (VI) contained P3: Tboulbou, P7: Metwia, P8: Ghannouch et P9: Zerkine (Provenance Gabès) populations. Finally the last group (VII) consisted of tow populations: P12: Dgach (Provenance Tozeur) et P17: Elgolaa (Provenance Kébili).

To evaluate the information contained in experimental data, correspondence factorial analysis (CFA) was applied considering all the monomorphics and polymorphics bands obtained simultaneously by the 5 RAPD primers. The first 2 axis accounted for $29.06 \%$. Axis 1 explained $15.35 \%$ of the inertia, however the axis 2 explained $13.71 \%$ of the inertia. The dispersion of alfalfa populations on the plan defined by axes 1 and 2 showed seven clusters of populations (I, II, III, IV, V, VI and VII). Theses clusters were similar to these obtained by the dendrogram illustrated in Figure 3 and contained the same populations. Grouping of lucerne genotypes using CFA confirmed the result obtained using UPGMA method based on RAPD data. Tunisian and Chinese alfalfa populations were clustered independently of both geographic origins.

\subsection{Genetic Diversity and Genotypes Relationships Obtained by ISSR Markers}

In the second part of our experiment, the genetic variation between 20 alfalfa populations was detected with five ISSR primers. These five primers were screened in this study and produced discrete and reproducible amplified DNA fragments (Figure 4). The five ISSR primers resulted in 51 different amplification products with 33 polymorphic RAPD bands for the 20 populations (Table 3).

Different levels of polymorphisms were detected since as the percentage of polymorphic bands (\%PB) ranged from 20 for A12 to 95.56 for UBC 890 primers, with an average of $57.78 \%$. 


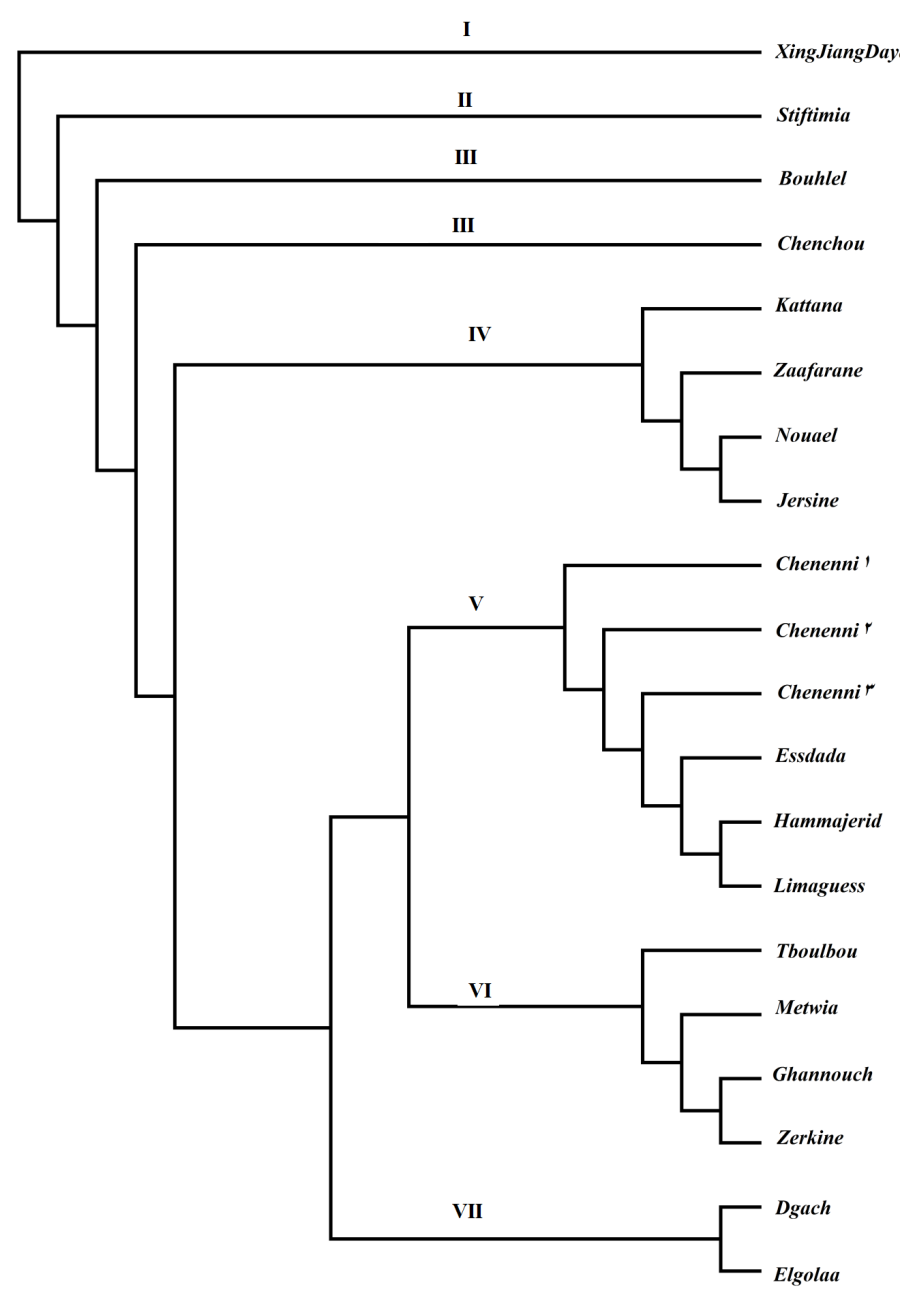

Figure 2. Dendrogram of the 20 Tunisian and Chinese alfalfa populations constructed by UPGMA methods using the similarity matrix generated by the Jaccard coefficient based on RAPD marker.

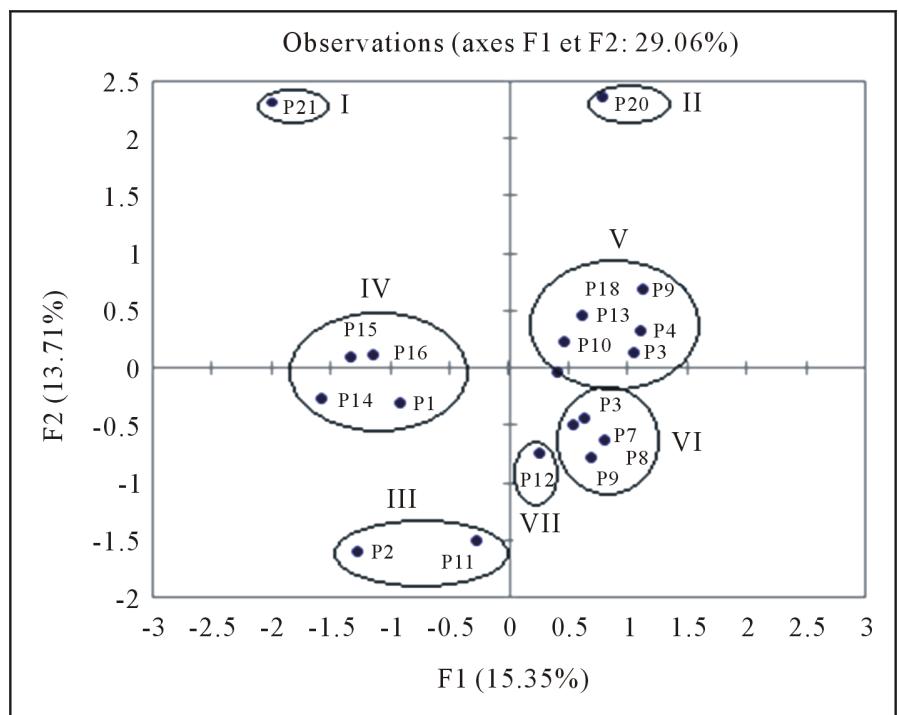

Figure 3. Plot of 20 Tunisian and Chinese alfalfa populations according to the tow first axes of the correspondence factorial analysis (CFA) based on 5 RAPD primers. 
MM P1 P2 P3 P4 P5 P6 P7 P8 P9 P10 P11 P12 P13 P14 P15 P16 P17 P18 P20 P21
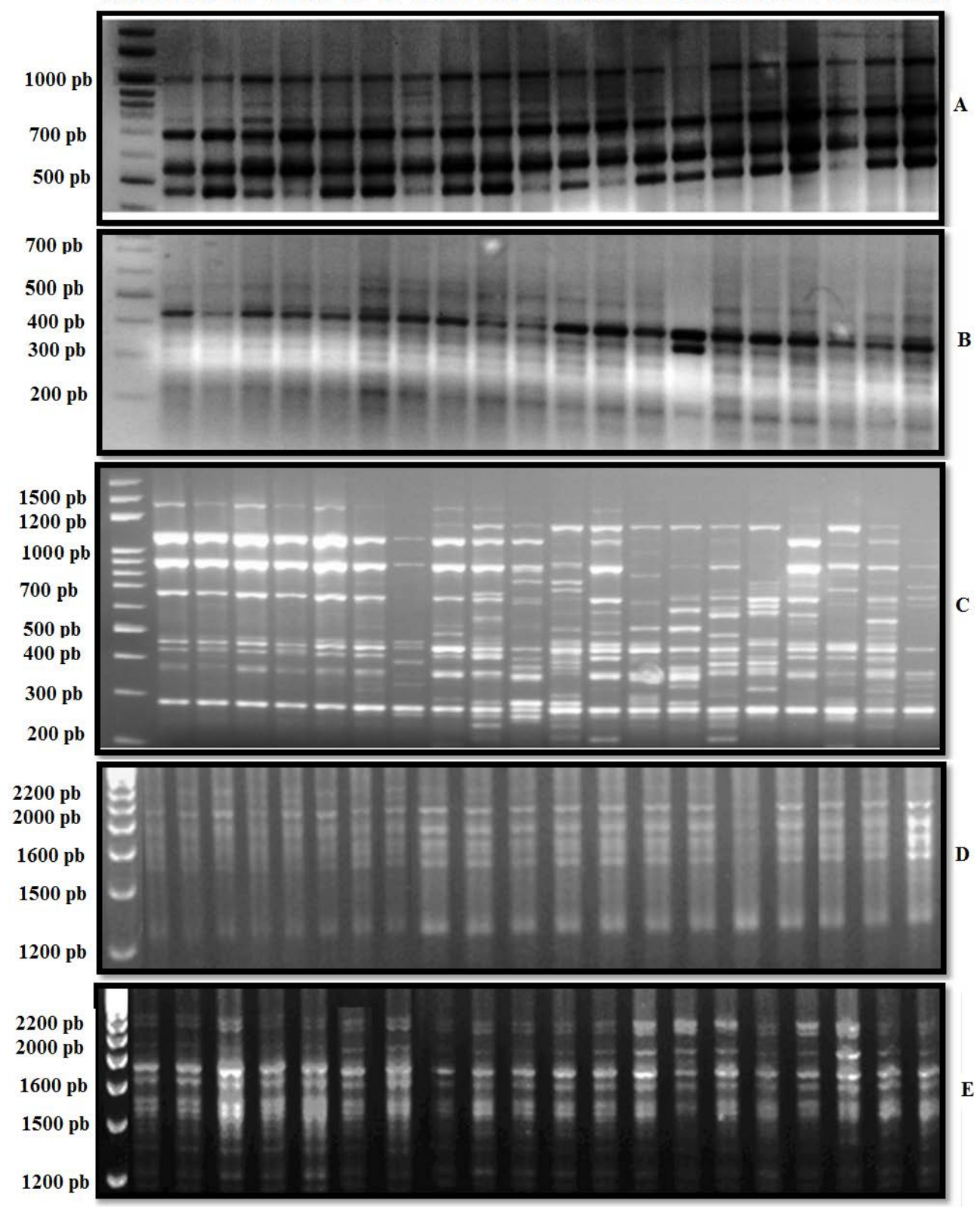

Figure 4. RAPD bands amplified with five primers: (A) A1, (B) Am2, (C) UBC 890, (D) A12 and (E) UBC 818, using DNA of 20 Tunisian and Chinese alfalfa samples. Numbers represent the populations according to Table 1. MM: Molecular Marker.

The percentage of polymorphic bands detected by RAPD marker was $64.7 \%$ and the average of polymorphic bands per RAPD primers was $12.94 \%$. The largest number of polymorphic bands (22) was produced with UBC 890 primer, and the least number of polymorphic bands (1) was obtained by A12. The 5 polymorphic primers exhibited variation with regard to Average Informativeness band (AvIb) and resolving power (Rp). However, estimates of the resolving power (Rp) showed a high rate of collective Rp (11.4) with an average of 2.28.

Moreover, as reported in Table 3, the Average Informativness band (AvIb) values varied from 0.29 showed by the primer UBC890 to 0.7 showed by the primer A12, with an average of 0.624 .

The similarity matrix (Table 5) showed that the highest similarity (0.97) was for the populations P4, P5, P6, P10, P13 and P18; P1, P14, P15 and P16, P2 and P11. The lowest similarity (0.6) was between the populations P21, P4, P1, P14, P18, P20 and P9. 
Table 5. Similarity matrix among 20 alfalfa populations based on data from 5 ISSR primers (51ISSR markers).

\begin{tabular}{|c|c|c|c|c|c|c|c|c|c|c|c|c|c|c|c|c|c|c|c|c|}
\hline & P1 & P2 & P3 & P4 & P5 & P6 & P7 & P8 & P9 & P10 & P11 & P12 & P13 & P14 & $1 P 15$ & P16 & P17 & P18 & P20 & P21 \\
\hline P1 & 1 & & & & & & & & & & & & & & & & & & & \\
\hline P2 & 0.97 & 1 & & & & & & & & & & & & & & & & & & \\
\hline P3 & 0.85 & 0.88 & 1 & & & & & & & & & & & & & & & & & \\
\hline P4 & 0.8 & 0.83 & 0.94 & 1 & & & & & & & & & & & & & & & & \\
\hline P5 & 0.85 & 0.82 & 0.94 & 0.89 & 1 & & & & & & & & & & & & & & & \\
\hline P6 & 0.85 & 0.83 & 0.94 & 0.94 & 0.94 & 1 & & & & & & & & & & & & & & \\
\hline P7 & 0.69 & 0.68 & 0.74 & 0.74 & 0.73 & 0.78 & 1 & & & & & & & & & & & & & \\
\hline P8 & 0.78 & 0.76 & 0.77 & 0.82 & 0.76 & 0.82 & 0.68 & 1 & & & & & & & & & & & & \\
\hline P9 & 0.74 & 0.73 & 0.78 & 0.74 & 0.78 & 0.78 & 0.61 & 0.76 & 1 & & & & & & & & & & & \\
\hline P10 & 0.71 & 0.69 & 0.8 & 0.75 & 0.79 & 0.8 & 0.7 & 0.73 & 0.79 & 1 & & & & & & & & & & \\
\hline P11 & 0.6 & 0.63 & 0.64 & 0.61 & 0.6 & 0.61 & 0.63 & 0.67 & 0.68 & 0.73 & 1 & & & & & & & & & \\
\hline P12 & 0.76 & 0.78 & 0.84 & 0.8 & 0.79 & 0.8 & 0.66 & 0.78 & 0.74 & 0.76 & 0.69 & 1 & & & & & & & & \\
\hline P13 & 0.69 & 0.71 & 0.73 & 0.68 & 0.68 & 0.68 & 0.63 & 0.71 & 0.64 & 0.69 & 0.71 & 0.74 & 1 & & & & & & & \\
\hline P14 & 0.66 & 0.69 & 0.66 & 0.62 & 0.65 & 0.62 & 0.56 & 0.68 & 0.62 & 0.67 & 0.68 & 0.71 & 0.79 & 1 & & & & & & \\
\hline P15 & 0.65 & 0.68 & 0.73 & 0.69 & 0.68 & 0.69 & 0.64 & 0.67 & 0.77 & 0.74 & 0.71 & 0.83 & 0.72 & 0.69 & 1 & & & & & \\
\hline P16 & 0.61 & 0.63 & 0.69 & 0.65 & 0.64 & 0.65 & 0.68 & 0.6 & 0.58 & 0.74 & 0.68 & 0.74 & 0.77 & 0.69 & 0.73 & 1 & & & & \\
\hline P17 & 0.8 & 0.78 & 0.89 & 0.84 & 0.89 & 0.89 & 0.69 & 0.73 & 0.74 & 0.84 & 0.64 & 0.84 & 0.68 & 0.66 & 0.73 & 0.74 & 1 & & & \\
\hline P18 & 0.73 & 0.76 & 0.77 & 0.73 & 0.72 & 0.73 & 0.6 & 0.67 & 0.76 & 0.82 & 0.75 & 0.78 & 0.71 & 0.68 & 0.76 & 0.68 & 0.77 & 1 & & \\
\hline P20 & 0.69 & 0.72 & 0.78 & 0.73 & 0.73 & 0.73 & 0.64 & 0.71 & 0.77 & 0.74 & 0.67 & 0.83 & 0.72 & 0.69 & 0.85 & 0.73 & 0.78 & 0.76 & 1 & \\
\hline P21 & 0.69 & 0.72 & 0.78 & 0.74 & 0.73 & 0.74 & 0.68 & 0.63 & 0.65 & 0.74 & 0.72 & 0.7 & 0.77 & 0.69 & 0.73 & 0.78 & 0.78 & 0.81 & 0.77 & 1 \\
\hline
\end{tabular}

The derived UPGMA dendrogram illustrated in Figure 5 has clustered the 20 populations into five main groups. The three first groups, labeled (I, II), successively, consisted of P21: Xinjiang Daye (Provence Chine) and P20: Stiftimia (Provence Kébili). The third group labeled (III) consisted of P2: Chenchou, P3: Tboulbou, P6: Chenenni 3, P8: Ghannouch and P9: Zerkine (Provence Gabès), P17: Elgolaa (Provence Kébili). The fourth group labeled (IV) consisted of P1: Kattana, P4: Chenenni 1, P5: Chenenni 2, P7: Metwia (Provence Gabès), P10: Essdada, P12: Dgach and P13: Hamma Jerid (Provenance Tozeur) and P18: Limaguess (Provenance Kébili). Finally the last group (V) consisted of tow populations: P15: Nouael and P16: Jersine (Provence Kébili).

To evaluate the information contained in this experimental data, correspondence factorial analysis (CFA) was applied considering all the monomorphics and polymorphics bands obtained simultaneously by the 5 ISSR primers (Figure 6). The first 2 axis accounted for $45.07 \%$. Axis 1 explained $24.60 \%$ of the inertia, however the axis 2 explained $20.47 \%$ of the inertia. The dispersion of alfalfa populations on the plan defined by axes 1 and 2 showed five clusters of populations (I, II, III, IV and V). Theses clusters were similar to these obtained by the dendrogram illustrated in Figure 4 and contained the same populations. Grouping of lucerne genotypes using CFA confirmed the result obtained using UPGMA method based on ISSR data. Tunisian and Chinese alfalfa populations were clustered independently of both geographic origins.

\section{Discussion}

A study is presently carried out on the genetic variability available in this specie. Codominant Molecular markers such as RAPD and ISSR were used to investigate the genetic diversity and to study the relationships between 
I

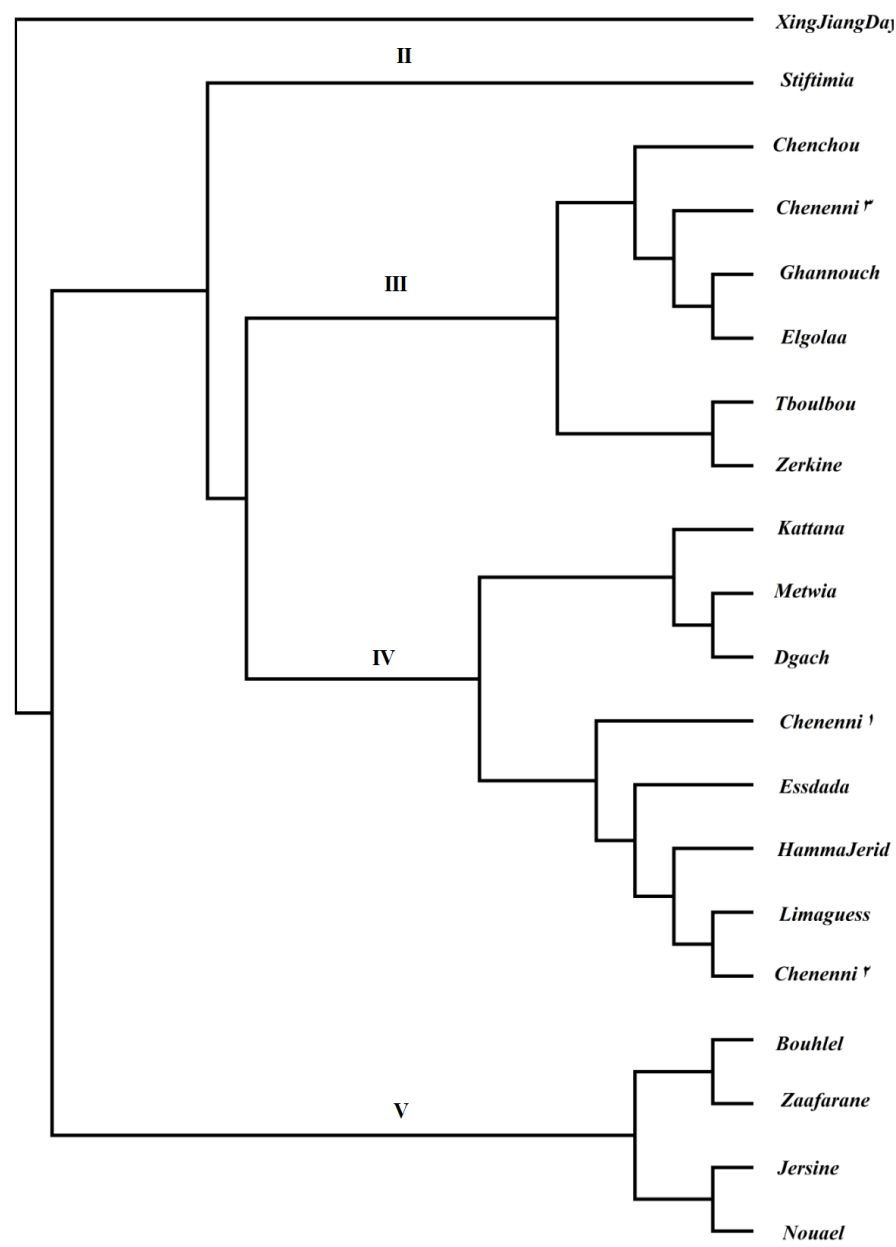

Figure 5. Dendrogram of the 20 Tunisian and Chinese alfalfa populations constructed by UPGMA methods using the similarity matrix generated by the Jaccard coefficient based on ISSR marker.

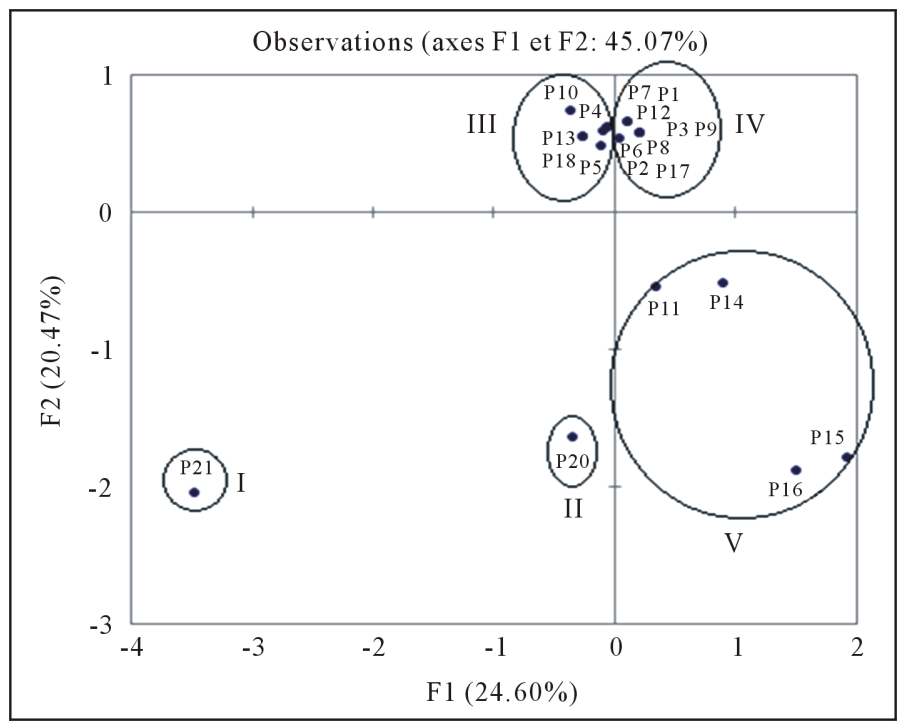

Figure 6. Plot of 20 Tunisian and Chinese alfalfa populations according to the tow first axes of the correspondence factorial analysis (CFA) based on 5 ISSR primers. 
20 populations of Tunisian and Chinese alfalfa. However in both of RAPD and ISSR markers, a set of 20 populations were analyzed in this study (Table 1). A total of 10 primers were screened for RAPD and ISSR PCR analysis. They were useful for characterizing the samples and produced strongly amplified polymorphic bands. The selected primers generated an appropriate amplification pattern with clear, consistent, and reproducible bands. In the present study the total number of amplified bands for RAPD markers was 44 of which 22 were polymorphic. Moreover, the average polymorphism displayed by this marker was 50\%. Many reports have been documented regarding genetic diversity of Medicago sativa L. using RAPD markers [8]-[13].

However, the total number of amplified bands for ISSR markers was 51 of which 32 were polymorphic. Moreover, the average polymorphism displayed by this marker was $64.7 \%$ however, nothing is know about the genetic diversity available within or between alfalfa populations based on ISSR marker except the previous study concerning the genetic diversity of some Mediterranean alfalfa populations (Medicago sativa L.) using ISSR marker [35].

The total variability that may be due, mainly, to interaction of several factors; 1) The reproductive aspect of the alfalfa (outcrossing); 2) the uncontrolled introduction of the varieties improved in Tunisia [36]; and 3) the insufficiency of the seeds [2].

The average polymorphism displayed by ISSR (64.7\%) was higher than that by RAPD (50\%), which suggested that the ISSR markers were superior to RAPD markers in the capacity of revealing more informative bands in a single amplification. ISSR markers proved, however, to be more useful, due to the high polymorphic percentage between alfalfa populations. ISSR results are more realistic comparing to RAPD results. Researchers who have compared RAPD and ISSR methods have found that ISSR markers exhibit higher levels of polymorphism or reproducibility compared with RAPD markers [37]-[40].

The dendrogram obtained by the Unweighted Pair Grouped of aggregation (Method Average (UPGMA) based on Jaccard distance and the Correspondance Factorial Analysis revealed a considerable variability between populations. However these analyses based on RAPD or ISSR markers showed respectively seven and five clusters of alfalfa populations. In the majority of group, the populations were different provinces. Genetic diversity observed in our analysis is not structured according to the geographic origins of population because the groups obtained in a classification aren't related to provinces. Benabderrahim et al. [2] show that the distribution of twenty cultivated populations of lucerne (Medicago sativa L) collected from different oasis of Tunisian south and evaluated for morphology and yield is not according to their geographic origins.

\section{Conclusion}

The results obtained here showed the possibility of genetic diversity analysis of alfalfa populations, based on dominant RAPD and ISSR markers treated with UPGMA method. RAPD and ISSR tools are very important for explaining genetic diversity and alfalfa population structures. The observed differences between studied populations should be studied further using other molecular approaches such as: RFPL, AFLP and SSR, these markers could be used in breeding program for improving vegetative and reproductive traits and to detect QTL (quantitative traits locus) for physiological traits related to abiotic stress adaptation.

\section{References}

[1] Julier, B., Huyghe, C. and Ecalle, C. (2000) Within- and Among-Cultivar Genetic Variation in Alfalfa: Forage Quality, Morphology and Yield. Crop Science, 40, 365-369. http://dx.doi.org/10.2135/cropsci2000.402365x

[2] Riday, H., Brummer, E.C., Campbell, T.A., Luth, D. and Cazcarro, P.M. (2003) Comparison of Genetic and Morphological Distance with Heterosis between Medicago sativa Subsp. sativa and Subsp. falcata. Euphytica, 131, 37-45. http://dx.doi.org/10.1023/A:1023050126901

[3] Benabderrahim, M.A., Haddad, M. and Ferchichi, A. (2009) Diversity of Lucerne (Medicago sativa L.) Populations in South Tunisia. Pakistan Journal of Botany, 41, 2851-2861.

[4] Guines, F., Julier, B., Ecalle, C. and Huyghe, C. (2003) Among- and Within-Cultivar Variability for Histological Traits of Lucerne (Medicago sativa L.) Stem. Euphytica, 130, 293-301. http://dx.doi.org/10.1023/A:1022885320517

[5] Jenczewski, E., Prosperi, J.M. and Ronfort, J. (1999) Evidence for Gene Flow between Wild and Cultivated Medicago sativa (Leguminosae) Based on Allozyme Markers and Quantitative Traits. American Journal of Botany, 86, 677-687. http://dx.doi.org/10.2307/2656577

[6] Zaccardelli, M., Gnocchi, S., Carelli, M. and Scotti, C. (2003) Variation among and within Italian Alfalfa Ecotypes by 
Means of Bio-Agronomic Characters and Amplified Fragment Length Polymorphism Analyses. Plant Breed, 122, 1-65. http://dx.doi.org/10.1046/j.1439-0523.2003.00750.x

[7] Julier, B., Flajoulot, S., Barre, P., Cardinet, G., Santoni, S., Huguet, T. and Huyghe, C. (2003) Construction of Two Genetic Linkage Maps in Cultivated Tetraploid Alfalfa (Medicago sativa) Using Microsatellite and AFLP Markers. BMC Plant Biology, 3-9.

[8] Brouwer, E.C., Bouton, J.H. and Kochert, G. (1995) Analysis of Annual Medicago Species Using RAPD Markers. Genome, 38, 362-367. http://dx.doi.org/10.1139/g95-047

[9] Crochemore, M.L., Huyghe, C. Kerlan, M.C. Durand, F. and Julier, B. (1996) Partitioning and Distribution of RAPD Variation in a Set of Populations of the Medicago sativa Complex. Agronomy, 16, 421-432. http://dx.doi.org/10.1051/agro:19960702

[10] Crochemore, M.L., Huygeh, C. and Julier, B. (1998) Structuration of Alfalfa Genetic Diversity Using Agronomic and Morphological Characteristics. Relationship with RAPD Markers. Agronomy, 18, 79-94. http://dx.doi.org/10.1051/agro:19980106

[11] Mengoni, A. Gori, A. and Bazzicalupo, M. (2000) Use of RAPD and Microsatellite (SSR) Variation to Assess Genetic Relationships among Populations of Tetraploid Alfalfa, Medicago sativa. Plant Breeding, 119, 311-317. http://dx.doi.org/10.1046/j.1439-0523.2000.00501.x

[12] Jenczewski, E., Prosperi, J.M. and Ronfort, J. (1999) Differentiation between Natural and Cultivated Populations of Medicago sativa (Leguminosae) from Spain: Analysis with Random Amplified Polymorphic DNA (RAPD) Markers and Comparison to Allozymes. Molecular Ecology, 8, 1317-1330. http://dx.doi.org/10.1046/j.1365-294X.1999.00697.x

[13] Dehghan-Shoar, M.J.G., Hampton, J.G. and Gardiner, S.E. (1997) Genetic Analysis among and within Populations Forming Ecotypes and Cultivars of Lucerne, Medicago sativa (Leguminosae), Using RAPD Fragments. Plant Systematics and Evolution, 208, 107-119. http://dx.doi.org/10.1007/BF00986085

[14] Brouwer, E.C., Bouton, J.H. and Kochert, G. (1993) Development of an RLFP Map in Diploid Alfalfa. Theoretical and Applied Genetics, 86, 329-332.

[15] Pupilli, F., Businelli, S., Paolocci, F., Scotti, C., Damiani, F. and Arcioni, S. (1996) Extent of RFLP Variability in Tetraploid Populations of Alfalfa, Medicago sativa. Plant Breeding, 115, 106-112. http://dx.doi.org/10.1111/j.1439-0523.1996.tb00883.x

[16] Kidwell, K.K., Austin, D.F. and Osborn, T.C. (1994) RFLP Evaluation of Nine Medicago Accessions Representing the Original Germplasm Sources for North American Alfalfa Cultivars. Crop Science, 34, 230-236. http://dx.doi.org/10.2135/cropsci1994.0011183X003400010042x

[17] Brummer, E.C., Kochert, G. and Bouton, J.H. (1991) RFLP Variation in Diploid and Tetraploid Alfalfa. Theoretical and Applied Genetics, 83, 89-96. http://dx.doi.org/10.1007/bf00229230

[18] Diwan, N., Bhagwat, A.A., Bauchan, G.R. and Cregan, P.B. (1997) Simple Sequence Repeat (SSR) DNA Markers in Alfalfa and Perennial and Annual Medicago Species. Genome, 40, 887-895. http://dx.doi.org/10.1139/g97-115

[19] Flajoulot, S., Ronfort, J., Baudouin, P., Barre, P., Huguet, T., Huyghe, C. and Julier, B. (2005) Genetic Diversity among Alfalfa (Medicago sativa) Cultivars Coming from a Breeding Program, Using SSR Markers. Theoretical and Applied Genetics, 111, 1420-1429. http://dx.doi.org/10.1007/s00122-005-0074-4

[20] Li, P., Wang, Y., Sun, X. and Han, J. (2009) Using Microsatellite (SSR) and Morphological Markers to Assess the Genetic Diversity of 12 Falcata (Medicago sativa spp. falcata) Populations from Eurasia. African Journal of Biotechnology, 8, 2102-2108.

[21] Williams, J.K., Kubelik, A.R., Livak, K.J., Rafalski, J.A. and Tingey, S.V. (1990) DNA Polymorphisms Amplified by Arbitrary Primers Are Useful as Genetic Markers. Nucleic Acids Research, 18, 6531-6535. http://dx.doi.org/10.1093/nar/18.22.6531

[22] Welsh, J. and McCeleand, M. (1990) Fingerprinting Genomes Using PCR with Arbitrary Primers. Nuclear Acids Research, 18, 7213-7218. http://dx.doi.org/10.1093/nar/18.24.7213

[23] Beebee, T. and Rowe, G. (2004) An Introduction to Molecular Ecology. Oxford University Press, Oxford, 346 p.

[24] Ferreira, M.E. and Grattapaglia, D. (1998) Introductao ao uso de marcadores moleculares em angalise genetica. EMBRAPA-CENARGEN, 220 p.

[25] Penner G.A., Bush, A., Wise, R., Kim, W., Domier, L., Kasha, K., Laroche, A., Scoles, G., Molnar, S. and Fedak, G. (1993) Reproducibility of Random Amplified Polymorphic DNA (RAPD) Analysis among Laboratories. Genome Research, 2, 341-345. http://dx.doi.org/10.1101/gr.2.4.341

[26] Adams, R.P., Flournoy, L.E. and Pandey, R.N. (1998) Obtaining Reproducible Patterns from Random Polymorphic DNA Amplification (RAPDs). Taxon, 42, 553-571. http://dx.doi.org/10.2307/1222534

[27] Zietkiewicz, E., Rafalski, A. and Labuda, D. (1994) Genome Fingerprinting by Simple Sequence Repeat (SSR)-Anchored 
Polymerase Chain Reaction Amplification. Genomics, 20, 176-183. http://dx.doi.org/10.1006/geno.1994.1151

[28] Wolfe, A.D., Xiang, Q.Y. and Kephart, S.R. (1998) Assessing Hybridization in Natural Populations of Penstemon (Scrophulariaceae) Using Hypervariable Intersimple Sequence Repeat (ISSR) Bands. Molecular Ecology, 7, 11071125. http://dx.doi.org/10.1046/j.1365-294x.1998.00425.x

[29] Ruas, P.M., Ruas, C.F., Rampim, L., Carvalho, V.P., Ruas, E.A. and Sera, T. (2003) Genetic Relationship in Coffea Species and Parentage Determination If Interspecific Hybrids Using ISSR (Inter-Simple Sequence Repeat) Markers. Genetics and Molecular Biology, 26, 319-327. http://dx.doi.org/10.1590/S1415-47572003000300017

[30] Sambrook, J., Frithsch, E.F. and Maniatis, T. (1989) Molecular Cloning: A Laboratory Manual. 2nd Edition, Cold spring Harbor Laboratory, Cold Spring Harbor, New York, San Francisco.

[31] Jaccard, P. (1908) Nouvelles recherches sur la distribution florale. Bulletin de la Société Vaudoise des Sciences Naturelles, 44, 223-270.

[32] Felsenstein, J. (1995) PHYLIP (Phylogeny Inference Package) Version 3.5. Department of Genetics, University of Washington, Seattle. Sneath, P.M.A. and Sokal, R.R. (1973) Numerical Taxonomy. W.H. Freeman and Company, San Francisco.

[33] Prevost, A. and Wilkinson, M.J. (1999) A New System of Comparing PCR Primers Applied to ISSR Fingerprinting of Potato Cultivars. Theoretical and Applied Genetics, 98, 107-112. http://dx.doi.org/10.1007/s001220051046

[34] Gilbert, J.E., Lewis, R.V., Wilkinson, M.J. and Galigari, P.D.S. (1999) Developing and Appropriate Strategy to Assess Genetic Variability in Plant Germplasm Collections. Theoretical and Applied Genetics, 98, 1125-1131. http://dx.doi.org/10.1007/s001220051176

[35] Touil, L., Guasmi, F., Farès, K. and Ferchichi, A. (2007) Genetic Diversity of Some Mediterranean Populations of the Cultivated Alfalfa (Medicago sativa L.) Using ISSR Markers. Biotechnology, 7, 808-812. http://dx.doi.org/10.3923/biotech.2008.808.812

[36] El Ghazzah, M. and Chalbi, N. (1995) Ressources génétiques et amélioration des plantes. In: Le progrès génétique passe-t-il par le repérage des gènes, Ed AUPELF-UREF, John Libbey Eurotxt, Paris, 123-129.

[37] Fang, D.Q. and Roose, M.L. (1997) Identification of Closely Related Citrus Cultivars with Inter-Simple Sequence Repeats Markers. Theoretical and Applied Genetics, 95, 408-417. http://dx.doi.org/10.1007/s001220050577

[38] Esselman, E.J., Jianqiang, L., Crawford, D.J., Windus, J.L. and Wolfe A.D. (1999) Clonal Diversity in the Rare Calamagrostis porteri ssp. insperata (Poaceae): Comparative Results from Allozymes and Random Amplified Polymorphic DNA (RAPD) and Inter Simple Sequence Repeat (ISSR) Markers. Molecular Ecology, 8, 443-451. http://dx.doi.org/10.1046/j.1365-294X.1999.00585.x

[39] Parsons, B.J., Newburg, H.J., Jackson, M.T. and Fordlioyd, B.V. (1997) Contrasting Genetic Diversity Relationships Are Revealed in Rice (Orysa sativa L.) Using Different Markers Types. Molecular Breeding, 3, 115-125. http://dx.doi.org/10.1023/A:1009635721319

[40] Qian, W., Ge, S. and Hong, D.Y. (2001) Genetic Variation within and among Populations of a wild Rice Oryza granulata from China Detected by RAPD and ISSR Markers. Theoretical and Applied Genetics, 102, 440-449. http://dx.doi.org/10.1007/s001220051665 